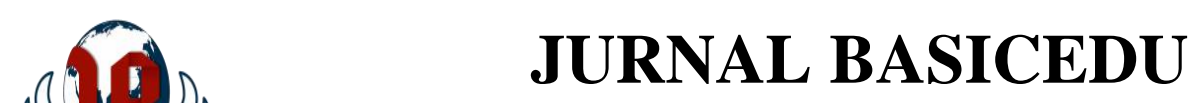

Volume 5 Nomor 3 Tahun 2021 Halaman 1252-1258

Research \& Learning in Elementary Education https://jbasic.org/index.php/basicedu

\title{
Problematika Pembelajaran Online Bagi Anak Berkebutuhan Khusus Di Sekolah Dasar Masa Pandemi Covid-19

\author{
Minsih $^{1 凶}$, Jatin Sri Nandang ${ }^{2}$, Wahyu Kurniawan ${ }^{3}$ \\ Program Pascasarjana Magister Pendidikan Dasar Universitas Muhammadiyah Surakarta ${ }^{1,2,3}$ \\ E-mail: min139@ums.ac.id ${ }^{1}$, jsnstudentpps@ums.ac.id ${ }^{2}$, wkstudentpps@ums.ac.id ${ }^{3}$
}

\begin{abstract}
Abstrak
Pelaksanaan pembelajaran secara daring pada masa pandemi Covid-19 menghadirkan permasalahan tersendiri bagi anak berkebutuhan khusus. Penelitian ini bertujuan mendeskripsikan permasalahan anak berkebutuhan khusus pada saat pembelajaran daring. Penelitian ini adalah penelitian kualititatif dengan teknik pengumpulan data wawancara mendalam, observasi dan dokumentasi dengan menggunakan triangulasi. Teknik analisisnya menggunakan teknik analisis data kualitatif dengan tahapan reduksi, verifikasi dan penarikan kesimpulan. Hasil penelitian menunjukkan bahwa permasalahan pembelajaran anak berkebutuhan khusus di era pandemic merupakan suatu permasalahan yang kompleks, dan di urai menjadi tiga factor, yaitu: 1) faktor Sekolah. Kesulitan dan ketidak-siapan pihak sekolah terutama guru kelas dan guru pendamping khusus sebagai pembimbing anak dalam melaksanakan pembelajaran online yang inovatif, 2) faktor Orang tua. Kurang menguasai teknologi, tidak memiliki pemahaman terkait dengan pendidikan anak berkebutuham khusus, 3) faktor Lingkungan. Penelitian ini berdampak pada keberlanjutan kualitas pembelajaran anak berkebutuhan khusus sehingga pihak terkait akan berusaha lebih baik lagi untuk menyediakan layanan.
\end{abstract}

Kata Kunci: Anak berkebutuhan khusus, pembelajaran online, guru pendamping khusus, orang tua.

\begin{abstract}
The implementation of online learning during the Covid-19 pandemic presents its own problems for children with special needs. This study aims to describe the problems of children with special needs during online learning. This research is a qualitative research which used in-depth interview, observation and documentation using triangulation as data collection technique. The analysis technique used qualitative data analysis techniques with stages of reduction, verification and conclusion. The results show that the learning problem of children with special needs in the pandemic is a complex problem, and is broken down into three factors, namely: 1) school sactor; difficulties and unpreparedness of the school, especially classroom teachers and special companion teachers as guides of children in implementing innovative online learning, 2) parents factor; the lack of technology mastery, lack of understanding related to education of children with special needs, 3) environmental factor. This research has an impact on the sustainability of the quality of learning for children with special needs so that related parties will try to do better in providing services.
\end{abstract}

Keywords: Children with special needs, online learning, special companion teachers, parents.

Copyright (c) 2021 Minsih, Jatien Sri Nandang, Wahyu Kurniawan

Corresponding author :

Email: min139@ums.ac.id

DOI $\quad$ : https://doi.org/10.31004/basicedu.v5i3.876

ISSN 2580-3735 (Media Cetak)

ISSN 2580-1147 (Media Online) 
1253 Problematika Pembelajaran Online Bagi Anak Berkebutuhan Khusus Di Sekolah Dasar Masa Pandemi Covid-19-Minsih, Jatien Sri Nandang, Wahyu Kurniawan

DOI : https://doi.org/10.31004/basicedu.v5i3.876

\section{PENDAHULUAN}

Guru sebagai tenaga pendidik profesional mempunyai tujuan untuk meningkatkan mutu pendidikan nasional serta memiliki kemampuan untuk mewujudkan tujuan pendidikan nasional. Salah satu kompetensi yang harus dimiliki oleh guru sebagaimana yang disebutkan dalam Undang-undang Nomer 14 tahun 2005 tentang guru dan dosen adalah kompetensi pedagogik. Kompetensi pedagogik adalah kemampuan guru dalam mengelola pembelajaran peserta didik. Kompetensi pedagogik merupakan kompetensi khas yang akan membedakan seorang guru dan profesi lainnya dan akan menentukan tingkat keberhasilan proses dan hasil belajar peserta didik. Dengan demikian guru memiliki tanggung jawab dalam merancang program pembelajaran yang sesuai dengan kompetensi yang telah ditetapkan (Agus, 2013).Untuk mengatur pelaksanaan pembelajaran di masa pandemi Covid-19 pemerintah melalui Kementerian Pendidikan dan Kebudayaan mengeluarkan Surat Edaran Nomor 4 Tahun 2020 Tentang Pelaksanaan Kebijakan Pendidikan dalam Masa Darurat Penyebaran Coronavirus Disease (Covid-19) poin ke 2 ketentuan pertama bahwa belajar dari rumah dilaksanakan melalui pembelajaran daring/jarak jauh untuk memberikan pengalaman belajar bermakna bagi siswa. Dengan harapan pembelajaran daring dapat digunakan sebagai pengganti kegiatan belajar mengajar di sekolah.

Pembelajaran jarak jauh menjadi alternatif terbaik yang dapat dilakukan agar pembelajaran dapat tetap berlangsung walaupun siswa berada di rumah. Pembelajaran daring adalah pembelajaran yang dilakukan menggunakan internet sebagi tempat menyalurkan ilmu pengetahuan (Syarifudin, 2020). Sesuai dengan dengan pendapat (Risalah et al., 2020) bahwa perkembangan teknologi merupakan bagian yang sulit dijauhkan dari pendidikan. Apalagi di masa pandemi Covid-19 saat ini, media sosial dan aplikasi yang ada pada smartphone menjadi hal penting untuk digunakan sebagai pembelajaran daring. Hal ini karena hampir semua pembelajaran dan tugas dibagikan dan dikumpulkan melalui media sosial atau aplikasi yang telah ditentukan oleh guru. Akan tetapi, selain dapat menjadi jembatan ilmu di masa pandemi Covid-19 antara guru dan peserta didik, kemajuan teknologi juga membutuhkan peran serta dari orang tua yaitu salah satuna penyediaan smartphone untuk pembelajaran daring (Risalah et al., 2020). Sesuai dengan pendapat (Handayani et al., 2020) bahwa ada beberapa hal yang menjadi hambatan antara lain, keterbatasan interaksi guru dalam menjelaskan materi sehingga banyak siswa yang tidak paham, dan ketidaksiapan orang tua dalam membimbing anaknya belajar sehingga kalau dibiarkan akan menganggu perkembangan anak.

Perkembangan anak berlangsung secara berkelanjutan dan terus menerus melewati beberapa fase pertumbuhan. Keberhasilan mencapai suatu tahap perkembangan akan sangat menentukan keberhasilan pada tahap perkembangan berikutnya. Pada proses perkembangan anak akan menemukan berbagai macam permasalahan dan gangguan yang berakibat pada ketidakoptimalan dalam mencapai perkembangannya. Anak yang memiliki permasalahan atau hambatan yang bersifat sementara (temporer) dapat ditangani melalui proses bimbingan, namun pada anak yang memiliki permasalahan yang bersifat permanen dan memiliki resiko berat, maka diperlukan penanganan atau intervensi khusus. Kelompok anak inilah yang kemudian dikenal sebagai anak berkebutuhan khusus. Pola pendampingan orang tua juga dituntun lebih diperbanyak porsinya sebagaimana riset (Studies, 2020) yang menyampaikan bahwa dari keseluruhan total delapan responden tersebut pola pendampingan belajar yang dilakukan dalam bentuk pendampingan yang dilakukan itu berbeda-beda sesuai dengan gaya orang tua. Pada intinya mereka tetap melakukan pola dengan mengarahkan, mendampingi, dan membimbing serta evaluasi belajar anak.

Pelaksanaan pembelajaran secara daring pada masa pandemi Covid-19 menghadirkan permasalahan tersendiri bagi guru, orang tua dan terutama bagi anak berkebutuhan khusus. Anak berkebutuhan khusus sulit melaksanakan pembelajaran secara online. Hal ini didasarkan pada penjelasan guru pemdamping khusus (GPK) yang menyatakan bahwa anak-anak berkebutuhan khusus mengalami kemunduran perkembangan kognitif, sosial, perilaku dan emosinya karena pembelajaran dilaksanakan secara online selama era pandemic. Orang tua yang menjadi pendamping belajar anak selama pandemic tidak memiliki pemahaman yang baik dan pengalaman 
dalam mengajar anak. Sehingga pihak sekolah mengharuskan orang tua anak menciptakan strategi dalam mendampingi anak berkebutuhan khusus sebagaimana pendapat berikut ini: Strategi pembelajaran yang bias dilksanakan di rumah antara lain: Pertama Memanusiakan hubungan dengan cara membangun relasi positif antara guru, siswa dan orang tua. Kedua, Memahami konsep dengan guru memandu belajar melalui penjelasan tujuan dan proses pembelajaran pada orang tua. Ketiga Membangun keberlanjutan dengan melakukan refleksi bersama orang tua (Hamidaturrohmah \& Mulyani, 2020)

Pada masa pandemi Covid-19 saat ini pembelajaran sangat bergantung pada memanfaatkan jaringan internet yang ada. Selaras dengan pendapat (Isman, 2016) bahwa dalam proses pembelajaran daring jaringan internet dimanfaatkan sebagai sesuatu yang harus ada pada proses pembelajaran daring. Pembelajaran online adalah pembelajaran yang dilakukan di dalam jaringan dimana pengajar dengan yang diajar tidak bertemu tatap muka secara langsung (Pohan, 2020).

Untuk melakukan pembelajaran daring dengan baik, prinsip yang harus dipenuhi harus sesuai dengan Surat Edaran (SE) Mendikbud No. 4 tahun 2020 diantaranya yaitu terselenggaranya pembelajaran yang bermakna, yaitu dengan memberikan pengalaman pada proses pembelajaran yang interkatif. Selain itu siswa tidak terbebani akan adanya tugas-tugas yang diberikan secara berlebihan oleh guru. Hal ini sesuai dengan pendapat (Munawar \& Pusari, 2013) menganai prinsip yang harus dipenuhi dalam penyelenggaraan pembelajaran online yaitu: Pertama, sistem pembelajaran harus sederhana sehingga mudah untuk dipeajari. Kedua, sistem pembelajaran harus dibuat personal atau pribadi supaya pengguna sistem satu dengan sistem yang lain tidak salng bergantung. Ketiga, sistem harus dibuat cepat dalam menemukan materi atau memberi jawaban dari hasil perancangan sistem yang dikembangkan. Adapun pembelajaran daring mempunyai beberapa kelebihan yaitu adanya keluwesan waktu dan tempat belajar, misalnya belajar dapat dilakukan si kamar, ruang tamu dan sebagainya serta waktu yang diseseuaikan misalnya pagi, siang, sore atau malam. Dapat mengatasi permasalahan mengenai jarak, misalnya peserta didik tidak harus pergi ke sekolah dahulu untuk belajar. Tidak ada batasan dan dapat mencakup area yang luas (Putria et al., 2020).

Siswa pada usia sekolah dasar adalah usia masih suka bermain (Sudarsana \& Dkk, 2020). Anak masih belum bisa membedakan mana yang baik atau tidak untuk dirinya sendiri dan pada tahap ini perkembangan siswa adalah masa dimana seseorang masih butuh bimbingan dan arahan dari orang tua. Hal ini membuat mereka sebenarnya nyaman untuk belajar dari rumah atau biasa disebut pembelajaran daring yang dapat memberikan gambaran positif dari orang tua nya sendiri, hal itu benar-benar terjadi apabila orang tua memahami betul karakter anak dan menjadi orang tua yang penyabar dalam membimbing anaknya belajar dirumah (Nurul, 2019). Pembelajaran daring juga masih membutuhkan peran orang tua peserta didik, mengingat usia anak sekolah dasar yang masih membutuhkan arahan dan bimbingan juga pengawasan dalam pembelajaran (Putria et al., 2020). Problematika pembelajaran daring

Secara umum istilah anak berkebutuhan khusus ditujukan pada anak yang mengalami keterbatasan atau keluarbiasaan, baik fisik, sosial, emosional maupun mental-intelektual, yang berpengaruh secara signifikan dalam proses pertumbuhan dan perkembangannya dibandingkan dengan anak-anak lain yang seusianya. (Takdir Ilahi, 2013) menyatakan bahwa anak berkebutuhan khusus adalah anak yang berbeda dari rata-rata anak normal dalam beberapa hal, meliputi ciri mental, kemampuan panca indera, kemampuan komunikasi, perilaku sosial atau sifat fisiknya. Heward menjelaskan anak berkebutuhan khusus adalah anak dengan karakteristik khusus yang berbeda dengan anak pada umumnya tanpa selalu menunjukkan pada ketidakmampuan mental, emosi maupun fisik. Mendasarkan pada istilah tersebut, anak berkebutuhan khusus merupakan anak yang unik dan memiliki karakteristik tersendiri yang membedakannya dengan anak-anak pada umumnya. Anak berkebutuhan khusus meliputi anak berkelainan (handicapped children) dalam proses tumbuh kembangnya (Baihaqi, MIF \& Sugiarmin, 2006). Beberapa penelitian di atas menjadi kajian yang menarik sebagai literatur sebelumnya yang memiliki perbedaan aspek dengan penelitian yang dilakukan ini. Penelitian ini lebih berfokus pada 
permasalahan yang muncul dalam pembelajaran daring (online) selama pandemic berlangsung. Pentingnya penelitian ini karena memiliki tujuan yang spesifik untuk mendeskripsikan dan merumuskan problematika pelaksanaan pembelajaran daring untuk anak berkebutuhan khusus.

\section{METODE}

Penelitian ini akan menggunakan jenis penelitian kualitatif. Penelitian kualitatif adalah jenis penelitian berdasarkan fakta-fakta yang terlihat nyata tanpa adanya bentuk hitungan dan data diperoleh dengan mendiskripsikan proses dan makna dengan memanfaatkan peneliti sebagai instumen kunci (Sugiarto, 2015) sehingga kehadiran peneliti dalam penelitian sangat menentukan keberhasilan. Penelitian ini dilaksanakan selama 3 bulan yaitu: bulan Oktober-Desember 2020 di Kota Surakarta. Informan dalam penelitian adalah guru kelas, guru pendaming khusus, anak berkebutuhan khusus dan orang tua. Subjek penelitian adalah anak berkebutuhan khusus. Teknik pengumpulan data yang digunakan yaitu teknik pengumpulan data wawancara, dokumentasi dan observasi. Uji keabsahan data dalam penelitian kualitatif ini meliputi uji Credibility, Transferability, Dependability, Confirmability. Teknik analisis data adalah proses pengumpulan secara sistematis untuk mempermudah peneliti dalam mendapatkan kesimpulan. Analisis data kualitatif bersifat induktif, yaitu analsisis berdasarkan data yang diperoleh. Teknik analisis data pada penelitian ini menggunakan model Miles dan Huberman yaitu: reduksi data, display data dan verifikasi data.

\section{HASIL DAN PEMBAHASAN}

Berdasarkan metode pengumpulan data yang dilakukan bahwa problematika pembelajaran online bagi anak berkebutuhan khusus selama masa pandemic COVID 19 ini memiliki beberapa factor yang dirumuskan sebagai berikut: Faktor Sekolah. Kesulitan dan ketidak-siapan pihak sekolah terutama guru kelas dan guru pendamping khusus sebagai pembimbing anak dalam melaksanakan pembelajaran online yang inovatif. Hal ini yang dirasakan oleh GPK salah satu guru pada sekolah inklusi di kota Surakarta yang berinisial Lth yang mengatakan:

Pembelajaran online bagi saya dan murid saya sangat menyulitkan, apalagi saya menegang tiga anak autis dengan spektrum yang berbeda. Kalua pembelajaran dilaksanakan secara virtual melalui aplikasi zoom, anakanak sulit focus sehingga saya berkesulitan melakukan pengkondisian kelas. Hal yang saya lakukan adalah meminta orang tua untuk mnjadi pendamping anak waktu zoom berlangsung, akan tetapi tidak semua orang tua bias melakukannya karena kesibukan mereka masing-masing.

Faktor Orang tua. Masih ditemukan orang tua yang kurang menguasai teknologi serta kesibukan orang dalam tanggung jawabnya mengurus rumah, mengurus anak-anak yang lain, dan masalah orang tua yang sibuk bekerja. Hal ini yang dinyatakan oleh salah satu orang tua: Karena saya bukanlah guru dan tidak memiliki pengalaman dan pemahaman mengajar yang baik, apalagi saya masih harus mengurus pekerjaan yang lainnya seperti urusan dapur untuk memasak, bersih-bersih rumah dan menyiapkan pembelajaran anak yang lain karena anak saya ada 3 dan ananda bukan anak tunggal dia punya kakak dan dua adik yang masih membutuhkan saya. Saya berharap situasi ini segera pulih dan anak-anak kembali ke sekolah.

Faktor Lingkungan. Pembelajaran online dianggap hal yang monoton sehingga siswa merasa bosan, karena minimnya interkasi siswa dengan teman sejawat secara nyata. Anggapan bahwa rumah bukanlah tempat yang tepat untuk belajar dan orang tua bukanlah guru bagi mereka yang tidak memiliki strategi mengajar yang tepat, dan penguasaan materinya lemah dan tidak memiliki background keilmuan pedagogic yang tepat, sehingga ketuntasan belajar di rumah masih minim. Hal ini yang rasakan oleh orang tua salah satu ABK yang berinisial MS: Dalam kondisi seperti ini kemampuan anak saya semakin menyusut, bahkan itu juga yang 
dirasakan oleh msma yang lain yang memiliki anak dengan gangguan Autis. Di sekolah anak bias belajar bersama teman sebaya dan stetiap minggu akan mengikuti layanan klinik terapi sesuai dengan gangguan yang dialami. Karena masa pandemic layanan klinis ini tidak bias beroperasi sehingga anak kami tidak memperoleh layanan itu.

Berdasarkan tiga faktor permasalahan di atas dapat disimpulkan bahwa permasalahan Pendidikan untuk anak berkebutuhan khusus selama pandemic ini sangat kompleks. Antara komponen satu dengan yang lainnya memiliki tingkat kesulitan yang berbeda-beda. Kompleksitas permasalahan ini dapat dirumuskan menjadi beberapa poin penting sebagai berikut: Ketidak siapan guru kelas dan guru pemndamping khusus dalam mengakomodasi kebutuhan ABK karena pelaksanaan pembelajaran secara online terutama pada mengelolaan kelas, pengkondisian belajar anak berkebutuhan khusus, dan menjalin komunikasi dengan baik pada ABK, berhentinya layanan klinis dan terapi bagi ABK yang biasanya dilaksanakan di sekolah, berhentinya aktivitas belajar anak di sekolah ikut menghentikan hubungan social anak dengan teman sejawat dan menjauhkan interaksi anak dengan lingkungan sekolah. Hal ini berdampak pada perkembangan social dan emosi anak, ketidak mampuan orang tua dalam menggantikan peran guru pendamping khusus (GPK) dalam memberikan pengalaman anak dalam belajar karena factor sibuk, minim pemahaman keilmuan tentang ABK dan lainnya, lingkungan belajar dan suasana belajar yang membosankan bagi siswa, komunikasi antara guru/ sekolah dengan pihak keluarga kurang berjalan dengan baik, anggapan siswa bahwa tempat belajar itu di sekolah dan yang mengajar itu adalah guru, sulitnya memahamkan pada ABK bahwa aktivitas belajar yang harus dilakukan di rumah dengan keterbatasan media, keterbatasan pemahaman orang tua tentang strategi membimbing ABK di saat belajar.

Kedelapan poin di atas merupakan permasalahan yang dialami anak-anak berkebutuhan khusus selama pembelajaran online karena era pandemic. Permasalahan tersebut tentunya harus menjadi catatan pihak sekolah dan pihak keluarga untuk ditingkatkan kualitasnya agar pembelajaran untuk anak berkebutuhan khusus ini berjalan dengan baik. Pembelajaran Online sebagaimana yang telah disampaikan oleh ( Handayani et al., 2020) bahwa implementasi pembelajaran daring (online) yang menuai beberapa problema, antara lain banyak orang tua dari murid sekolah dasar yang kurang memahami dan mengerti mengunakan teknologi, waktu yang harus dibagi dengan keharusan untuk mencari nafkah. Hal ini juga senada dengan (Mutaqinah \& Hidayatullah, 2020) yang menyatakan bahwa kendala-kendala yang dihadapi guru berupa keterbatasan kuota/jaringan, kesulitan mengontrol siswa sedangkan bagi orang tua akses internet dan terbatasnya fasilitas gadget serta kesulitan mengatur waktu dan proses mendampingi anak belajar. Apalagi bagi anak berkebutuhan khusus yang memiliki hambatan dalam belajar. Pada proses pelaksanaan pembelajarannya ABK harus di dukung oleh system yang optimal (Minsih et al., 2020)

Berdasarkan pada penelitian (Amell, 2020) pembelajaran online kurang efektif diterapkan karena faktor kurangnya sarana dan prasarana serta ketidaksiapan edukasi teknologi. Hal yang sama juga dinyatakan oleh Hamdani dan Priatna (2020) yang menyimpulkan bahwa tingkat efektifitas pembelajaran dari 8 indikator yang diteliti yaitu sekitar 66,97 \%. Hal ini senada dengan penelitian yang menyatakan bahwa: Pembelajaran untuk anak berkebutuhan khusus pada masa pandemi Coronavirus Disease 2019 (COVID-19) di sekolah inklusi, yaitu; (1) guru dan orangtua dianggap kurang mampu dalam pembelajaran jarak jauh, (2) Orang tua tidak bias mengakses internet, (3) Anak malas untuk melakukan pembelajaran jarak jauh (Dewi et al., 2020) Ketiga temuan tersebut senada dengan beberapa temuan yang ditemukan dalam penelitian ini yaitu: kekurangan dari pihak sekolah dan keluarga serta factor intrinsik dari dalam diri anak.akan tetapi dalam penelitian (Dewi et al., 2020) tidak dijelaskan secara rinci dan komprehensif selain dari tiga poin tersebut di atas sedang dalam penelitian ditemukan delapan unsur masalah pembelajaran online.

Berdasar pada permasalahan yang telah dibahas di atas maka dibutuhkan beberapa strategi pembelajaran terbaik untuk ABK selama pembelajaran daring. Hal ini dianggap urgen karena permasalahan ini sudah berlangsung selama dua semester. Kajian tentang strategi pembelajaran daring untuk ABK ini sudah dilakukan 
1257 Problematika Pembelajaran Online Bagi Anak Berkebutuhan Khusus Di Sekolah Dasar Masa Pandemi Covid-19-Minsih, Jatien Sri Nandang, Wahyu Kurniawan

DOI : https://doi.org/10.31004/basicedu.v5i3.876

oleh beberapa penelitian diantaranya yaitu: Strategi pengajaran yang diindividualisasikan yaitu pengajaran yang disesuaikan dengan karakter individu, 2. Pembelajaran kooperatif, 3. Strategi modifikasi perilaku. 4. Inovasi media pembelajaran dan strategi belajar. 4. Membangun harmoni komunikasi yang baik dengan orang-orang terkait (Hamidaturrohmah \& Mulyani, 2020). Hal senada juga sesuai dengan hasil penelitian ( Handayani et al., 2020)bahwa pembelajaran daring dapat terlaksana dengan baik apabila adanya kerjasama antara guru, siswa dan orang tua dalam belajar dirumah, bimbingan penuh pada anak, dan kesiapan orang tua untuk meluangkan waktunya yang merupakan satu-satunya pilihan ditengah pendemi global Covid -19 walaupun tidak efektif bagi anak usia sekolah dasar. Riset ini akan menjadi sumbangan bagi kemajuan penyelenggaraan pendidikan inklusif untuk anak berkebutuhan khusus selama masa pandemic. Walau riset ini memiliki keterbatasan terkait waktu saat pengumpulan data, karena suasana akademik yang social distancing sehingga kurang oftimal.

\section{KESIMPULAN}

Beberapa hal yang dapat diambil dari pembahasan di atas adalah bahwa: Permasalahan pembelajaran daring untuk anak-anak berkebutuhan khusus bahwa selama belajar secara daring ini dapat dirumuskan sebagai berikut: Faktor Sekolah. Ketidak-siapan pihak sekolah terutama guru kelas dan guru pendamping khusus sebagai pembimbing anak dalam melaksanakan pembelajaran online. Faktor Orang tua. Masih ditemukan orang tua yang kurang menguasai teknologi serta kesibukan orang dalam tanggung jawabnya mengurus rumah, mengurus anak-anak yang lainnya sampai pada masalah pada orang tua yang bekerja. Faktor Lingkungan. Pembelajaran online dianggap hal yang monoton sehingga siswa merasa bosan, karena minimnya interkasi siswa dengan teman sejawat secara nyata. Anggapan bahwa rumah bukanlah tempat yang tepat untuk belajar dan orang tua bukanlah guru bagi mereka yang tidak memiliki strategi mengajar yang tepat, dan penguasaan materinya lemah dan tidak memiliki background keilmuan pedagogic yang tepat, sehingga ketuntasan belajar di rumah masih minim. Penelitian ini berdampak pada keberlanjutan kualitas pembelajaran anak berkebutuhan khusus sehingga pihak terkait akan berusaha lebih baik lagi untuk menyediakan layanan.

\section{DAFTAR PUSTAKA}

Agus, S, Farid. 2013. Peningkatan Efektivitas Pada Proses Pembelajaran. MATHEdunesa, 2(1).

Ameli, A., Hasanah, U., Rahman, H., dan Putra, A. M. 2020. Analisis keefektifan pembelajaran online di masa pandemi COVID-19. Mahaguru: Jurnal Pendidikan Guru Sekolah Dasar, 2(1), 28-37.

Baihaqi, MIF dan Sugiarmin, M. 2006. (2006). Memahami dan Membantu Anak ADHD. Bandung: PT Refika Aditama.

Dewi, N. Fadilah, dan Rahmah. 2020. Problematika Pembelajaran Untuk Anak Berkebutuhan Khusus Pada Masa Pandemi Covid-19 Di Sekolah Inklusi Dan. Jurnal Pendidikan Inklusi, 4, 1-10. https://journal.unesa.ac.id/index.php/ji/article/view/10913/4740

Hamidaturrohmah, H., dan Mulyani. 2020. Strategi Pembelajaran Jarak Jauh Siswa Berkebutuhan Khusus Di Sd Inklusi Era Pandemi Covid-19. ELEMENTARY: Islamic Teacher Journal, 8(2), 247. https://doi.org/10.21043/elementary.v8i2.7907

Handayani, R., Arif, M., dan Syam. 2020. Pembelajaran Daring Pada Anak Usia Sekolah Dasar Masa Pendemi Covid-19 Di Kecamatan Pauh Kota Padang. Jurnal Kepemimpinan Dan Pengurusan Sekolah, 5(2). https://doi.org/10.34125/kp.v5i2.516

Handayani, T., Khasanah, H. N., dan Yosintha. 2020. Pendampingan Belajar Di Rumah Bagi Siswa Sekolah Dasar Terdampak Covid-19. Abdipraja : Jurnal Pengabdian Kepada Masyarakat, 1(1), 107-115.

Isman. 2016. Pembelajaran Moda Dalam Jaringan (MODA JARINGAN).

Minsih, Mujahid, Imam., dan Suparno. 2020. Supporting system in inclusive education: A case study from 
1258 Problematika Pembelajaran Online Bagi Anak Berkebutuhan Khusus Di Sekolah Dasar Masa Pandemi Covid-19-Minsih, Jatien Sri Nandang, Wahyu Kurniawan

DOI : https://doi.org/10.31004/basicedu.v5i3.876

Indonesian elementary school. International Journal of Scientific and Technology Research, 9(3), 52565261.

Munawar, M, dan Pusari, R. 2013. Pengembangan model pembelajaran inovatif melalui pendekatan in house training berbasis kearifan budaya lokal. 2(1), 1-13.

Mutaqinah, R., \& Hidayatullah. 2020. Implementasi Pembelajaran Daring (Program BDR) Selama Pandemi Covid-19 di Provinsi Jawa Barat. Jurnal Petik, 6(2), 86-95. https://doi.org/10.31980/jpetik.v6i2.869

Nurul, D. 2019. Efektifitas Pembelajaran Berbasis Daring: Sebuah Bukti Pada Pembelajaran Bahasa Inggris. Jurnal TATSQIF, 17, 12-13.

Pohan, A. E. 2020. Konsep Pembelajaran Daring Berbasis Pendekatan Ilmiah. Cv. Sarnu Untung.

Putria, H., Maula, L. H., dan Uswatun, D. A. 2020. Analisis Proses Pembelajaran Dalam Jaringan (DARING) Masa Pandemi COVID-19 pada Guru Sekolah Dasar. Jurnal Basicedu, 4(4), 861-872. https://doi.org/10.31004/basicedu.v4i4.460

Risalah, A., Ibad, W., Maghfiroh, L., Azza, M. I., Cahyani, S. A., dan Ulfayati, Z. A. 2020. Dampak Pandemi Covid-19 Terhadap Kegiatan Belajar Mengajar di MI / SD ( Studi KBM Berbasis Daring Bagi Guru Dan Siswa ). 1(1), 10-16.

Studies, M. 2020. Academica. 4 (December).

Sudarsana, I. K., Dkk. 2020. COVID-19 Perspektif Pendidikan. Yayasan Kita Menulis.

Sugiarto, E. 2015. Menyusun Proposal Penelitian Kualitatif: Skripsi dan Tesis: Suara Media. CV. Solusi Distribusi.

Syarifudin, A. S. 2020. Impelementasi Pembelajaran Daring Untuk Meningkatkan Mutu Pendidikan Sebagai Dampak Diterapkannya Social Distancing. Metalingua: Jurnal Pendidikan Bahasa Dan Sastra Indonesia, 5(1), 31-34.

Takdir Ilahi, M. 2013. Pendidikan Inklusif: Konsep dan Aplikasi. In Ar-Ruzz Media, Yogyakarta. 